\title{
INTERVENTION OF RARELY SEEN CATHETER LOSS DURING PERMANENT TUNNELED HEMODIALYSIS CATHETERIZATION: A CASE REPORT
}

\author{
Emced Khalil \\ ${ }^{1}$ Department of cardiovascular surgery, \\ Ordu university research and education hospital, Ordu, Turkey
}

Primljen/Received 09. 05. 2020. god.

Abstract: Introduction: In patients with end-stage renal disease (ESRD), permanent hemodialysis cathetersare often used by performing percutaneous catheterization to create a permanent vascular access. To the best of our knowledge, no cases with accidental loss of catheter piece during hemodialysis catheter replacement or during its retrieval under scopy has been reported in the literature yet.

Case report: It was decided to retrieve the right permanent dialysis catheter of a 54-year-old woman, who had received a temporary dialysis catheter due to the development of catheter site infection in her $3^{\text {rd }}$ permanent catheter (the first two were changed due to thrombosis). Due to excess adhesion in the region, the retrieval of the catheter was complicated, only half of it (proximal piece after cutting into two) was removed, while the distal section slipped and migrated to the right subclavian vein, up to the right atrium. The diagnosis was confirmed by chest radiographs showing that the distal piece of the catheter piece was in the right subclavian vein and right atrium. The catheter piece was retrieved through a minor invasive procedure made possible by scopy without any further complications.

Conclusion: Permanent dialysis catheters should ideally be placed under scopy. Also, when the retrieval of a catheter is planned, cutting from any part of the catheter should never be performed.

Key words: hemodialysis, replacement failure, catheter, complication.

\section{INTRODUCTION}

Hemodialysis is the basis of treatment in patients with end-stage renal disease (ESRD) that are on the waiting list for a kidney transplant. As noted in many hemodialysis guidelines, arteriovenous fistulas (AVF)
Prihvaćen/Accepted 20. 06. 2020. god.

are very practical and have better success than any other vascular access route (1). While there are efforts to increase AVF in ESRD patients, there are also a great number of patients undergoing vascular surgery for the placement of tunneled catheters for hemodialysis. Some common complications, such as catheter infection and thrombosis, perforation, fragmentation and emboli into the main central vessels, and the rare complication of a catheter adhering to the superior vena cava (SVC) and right atriumare reported in the literature (2). Furthermore, aging and accompanying diseases in the population of ESRD patients may prevent creation of an AVF; thus, permanent catheter placement becomes the only alternative (3). As such, dialysis catheters remain as a vital option to continue renal-replacement therapy in patients that do not have a possibility for vascular access and also those with failure.

Hemodialysis catheters were originally developed for short- and medium- term hemodialysis access to provide permanent access during AVF maturation. Schwab et al. conducted the first study in the literature that demonstrated the effectiveness of hemodialysis catheters in 1988 (4). In the following two decades, the use of these catheters gained extreme popularityas semi-permanent catheters that enabled reliable access in patients with chronic hemodialysis (5). Reasons for this unprecedented increase in popularity included the ease of placement, increased numbers of elderly and diabetic patients whose veins were not suitable for AVF, and patients' preferences (4). With the widespread use of these catheters, significant experience was gained and the possible complications were identified and minimized. However, serious risks still exist and can be associated with patient-related characteristics (6) and other factors (2). 
Here, we present a patient who suffered catheter loss in permanent tunneled hemodialysis catheterization and surgical retrieval of the catheter piece through the $2^{\text {nd }}$ intercostal space under scopy.

\section{CASE REPORT}

The patient was a 54-year-old woman who was scheduled for semi-urgent catheter removal due to septicemia and non-response to broad-spectrum antibiotics.

In the patient history, a brachiocephalic AVF had been created on the left arm after dialysis for 3 years, two of which had been with hypertension. The patient had thrombosis 2 years later, and this time a radiocephalic AVF fistula was created in the right forearm which also had a similar fate within 6 months. Thus, a permanent dialysis catheter was placed into the right subclavian vein to enable dialysis. During follow-up, she had clinical findings suggestive of catheter infection; after consultation with the nephrology department, the catheter was removed due to a diagnosis of dialysis catheter infection that had been ongoing for 5 months. Meanwhile, a temporary dialysis catheter was placed into the patient's left internal jugular vein. The removal of the right subclavian permanent catheter of the patient was scheduled in two steps by performing a $1 \mathrm{~cm}$ incision from the old incision site under local anesthesia in the operating room and cutting from the middle, followed by retrieval of both pieces in rapid succession. After standard surgical approach, the middle part was reached under the skin; however, we encountered excessive adhesions throughout the region.

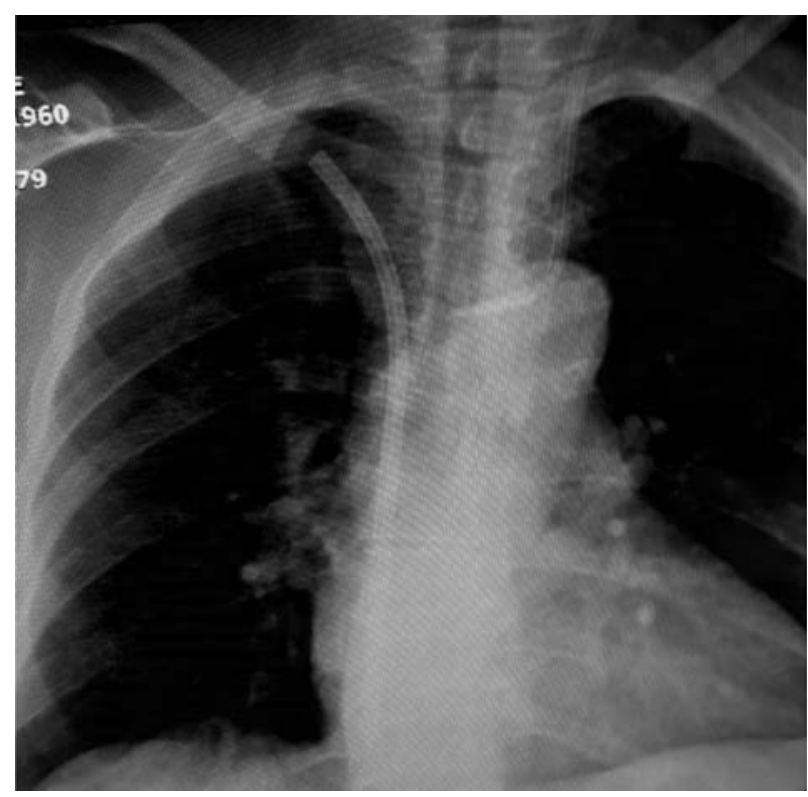

Figure 1. On the X-ray, the distal tip of the permanent catheter is seen in the inferior vena cava and right atrium, and on the other side, the tip of the left internal jugular vein catheter can be observed

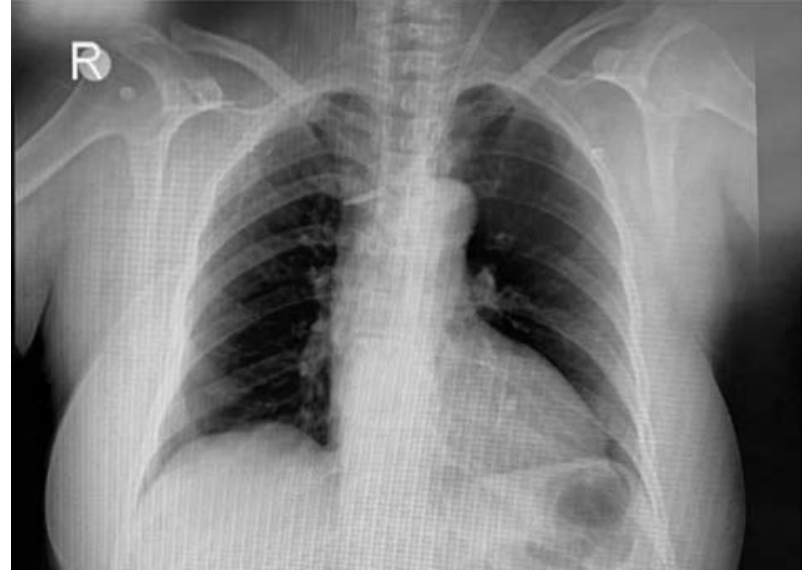

Figure 2: Post-operative control X-ray, the temporary dialysis catheter is observed in the left internal jugular vein

The catheter was cut after clamping both pieces to separate clamps, while the proximal part of the catheter was easily retrieved, the distal part slipped from the second clamp and was lost; it was found that it had migrated towards the vena cava superior and right atrium (Figure 1).

There was no deterioration in the patient's vital signs or general condition. After ensuring that the patient remained stable, a fast council was held and a decision for emergency action was made. Firstly, the patient was put under general anesthesia and intubated. After surgical antisepsison the whole chest region of the patient, sterile covering was performed. A $5 \mathrm{~cm}$ incision was made through the 2nd intercostal space under the right infraclavicular region and subclavian vein was reached. Then, we managed to hold the distal tip of the distal piece using a long clamp in the subclavian vein, under scopy. The catheter piece was then carefully retrieved with the aid of scopy. The subclavian vein was repaired and the incisions were closed anatomically. A control X-ray was taken while the patient remained on the operating table (Figure 2).

The patient was extubated and taken to the intensive care unit. The general condition of the patient during follow-up was good and no coagulopathy was detected in the patient. The patient's normal dialysis program was continued.

\section{DISCUSSION}

After loss of the distal piece of the dialysis catheter, the patient was successfully operated for the retrieval of the piece with a relatively less-invasive method, especially considering the possibility that more extensive approaches may have been required. The subclavian vein was accessed through a $5 \mathrm{~cm}$ incision in the right-side $2^{\text {nd }}$ intercostal space. The use of a long clamp under scopy was critical to be able to grab the catheter 
piece that was lodged within the subclavian vein. If this method was not successful, it was thought that the catheter piece would be removed from the right atrium by performing a right thoracotomy. Thanks to this method, a less invasive approach was used.

Although the best vascular access route for hemodialysis treatment is undoubtedly AVF formation, the prevalence hemodialysis catheter use is increasing in ESRD patients (7). The advantages of permanent central venous catheters are that they can be placed quickly and easily and allow immediate access to hemodialysis and missing cardiac volume load in annon-traumatic, and therefore, painless way. The disadvantages of permanent central venous catheters are that they have a significantly higher complication rate than other vascular access options.

In our experience, the key factor in catheter function and survival is the expertise of the team performing catheter placement and catheter care in dialysis units. Careful evaluation of the access point prior to implantation with the use of ultrasound, appropriate choice of catheter length according to body size, as well as placement localization and strict compliance with asepsis rules during catheter placement, are critical for success. Additionally, regular maintenance of the hemodialysis connections and the catheter are the post-intervention cornerstones of sustained and safe use of these catheters.

Considering the increase in the average age of dialysis patients in developing countries and the increase of dialysis times required by these patients, it is concluded that vascular surgery facilities cannot continue to provide sufficient service in response to the increasing number of hemodialysis patients. Even though suggesting AVF whenever possible is a good approach to reduce this excessive workload burden, it is critical to note that they are, indeed, very reliable and must be used wisely to ensure the best possible results for patients. Forauer et al. have reported various catheter-induced histological venous wall changes (8). They found that short-term catheter use caused endothelial damage in the vascular wall adjacent to the catheter in focal areas; whereas, long-term catheter use caused wall thickening and bridges between the catheter and the venous wall. The issue of managing catheters causing intravascular adhesions has not been adequately discussed in the medical literature. Traction of the catheter, which is the first method used to remove the catheter from the central vein, can cause severe vascular, atrial and tricuspid valve damage. When removing the catheters, it is a reasonable method to cut them from the venous area where they are placed (9). However, various complications, including inability to retrieve the catheter piece, have been reported while applying this method $(10,11,12)$. Thoracotomy might be considered as the last option for treatment. Ideally, thoracotomy with cardiopulmonary bypass should be avoided to retrieve catheters, because this operation is associated with severe morbidity and possible mortality. Among the various recommended techniques to retrieve an adherent catheter, interventional venocavagram exploration of the catheter seems to be a worthwhile option because this method might result in fewer complications than other procedures.

As a result, we conclude that permanent dialysis catheters should ideally be placed under scopy. Also, when the retrieval of a catheter is planned, cutting from any part of the catheter should never be performed. Since this procedure has a risk for mortal complications, the patient must be informed about this before the procedure and the procedure must be carried out in the operating room.

\section{Abbreviations \\ ESRD - end-stage renal disease \\ AVF - arteriovenous fistulas \\ SVC - superior vena cava}

Conflict of Interests: The authors declare that there are no conflicts of interest related to this article.

Funding: None

\section{Licensing}

This work is licensed under a Creative Commons Attribution 4.0 International (CC BY 4.0) License.

\title{
Sažetak
}

\section{REŠAVANJE RETKO VIĐENOG GUBITKA HEMODIJALIZNOG KATETERA TOKOM NJEGOVE ZAMENE: PRIKAZ SLUČAJA}

\author{
Emced Khalil \\ ${ }^{1}$ Department of cardiovascular surgery, \\ Ordu university research and education hospital, Ordu, Turkey
}

Sažetak: Kod pacijenata sa terminalnom bubrežnom insuficijencijom, dijalizni kateter se često koristi kao trajni vaskularni pristup za sprovođenje hemodijalize perkutanom kateterizacijom. Koliko je nama po- 
znato, u literaturi do sada nije zabeležen ni jedan slučaj slučajnog gubitka dela katetera tokom njegove zamene ili vađenja pod kontrolom skopije.

Prikaz slučaja: Odlučeno je da se zameni desni trajni dijalizni kateter kod pacijentkinje stare 54 godine, kojoj je prethodno plasiran privremeni dijalizni kateter zbog razvoja infekcije trećeg trajnog dijaliznog katetera (prethodna dva su zamenjena zbog tromboze). Zbog izraženih okolnih priraslica, zamena trajnog dijaliznog katetera je bila propraćena komlikacijama, samo polovina (gornji kraj nakon presecanja na pola) je izvučena, dok je donji kraj katetera skliznuo i migrirao

\section{REFERENCES}

1. Sequeira A, Sachdeva B, Abreo K. Uncommon complications of long-term hemodialysis catheters: adhesion, migration, and perforation by the catheter tip. Semin Dial. 2010; 23(1): 100-4.

2. Banerjee S. Dialysis catheters and their common complications: an update. Scientific World Journal. 2009; 9: 1294-9.

3. Gianotti MR, da Silva NM. Dialysis in the elderly patient: a challenge of the XXI century-narrative review. J Bras Nefrol. 2013; 35(2): 132-41.

4. Little MA, O'Riordan A, Lucey B, Farrell M, Lee M, Conlon PJ, et al. A prospective study of complications associated with cuffed, tunnelled haemodialysis catheters. Nephrol Dial Transplant. 2001; 16(11): 2194-200.

5. Kumwenda MJ, Wright FK, Haybittle KJ. Survey of permanent central venous catheters for haemodialysis in the UK. Nephrol Dial Transplant. 1996; 11(5): 830-2.

6. Wang K, Wang P, Liang X, Lu X, Liu Z. Epidemiology of haemodialysis catheter complications: a survey of 865 dialy-

\section{Correspondence to/Autor za korespondenciju}

Dr Emced Khalil

Ordu university, Department of cardiovascular surgery

Ordu. Turkey

Email: emjedkhalil@gmail.com

Cell phone: 00905052401565 u desnu subklavijalnu venu, sve do desne pretkomore. Dijagnoza je potvrđena radiografijom grudnog koša koja je pokazala da je distalni deo dijaliznog katetera $\mathrm{u}$ desnoj subklavijalnoj veni i desnoj pretkomori. Deo katetera je izvučen manjom invazivnom procedurom uz pomoć skopije, bez daljih komplikacija.

Zaključak: Stalni dijalizni kateteri u idealnom slučaju trebaju biti postavljeni pod kontrolom skopije. Takođe, kada se planira ukljanjanje katetera, presecanje bilo kojeg dela katetera se nikad ne sme uraditi.

Ključne reči: hemodijaliza, neuspešna zamena, kateter, komplikacija.

sis patients from 14 haemodialysis centres in Henan province in China. BMJ Open. 2015; 5(11): e007136.

7. Malas MB, Canner JK, Hicks CW, Arhuidese IJ, Zarkowsky DS, Qazi U, et al. Trends in incident hemodialysis access and mortality. JAMA Surg. 2015; 150(5): 441-8.

8. Forauer AR, Theoharis C. Histologic changes in the human vein wall adjacent to indwelling central venous catheters. J Vasc Interv Radiol. 2003; 14(9 Pt 1): 1163-8.

9. Jones SA, Giacomantonio M. A complication associated with central line removal in the pediatric population: retained fixed catheter fragments. J Pediatr Surg. 2003; 38(4): 594-6.

10. Thein H, Ratanjee SK. Tethered hemodialysis catheter with retained portions in central vein and right atrium on attempted removal. Am J Kidney Dis. 2005; 46(3): e35-9.

11. Field M, Pugh J, Asquith J, Davies S, Pherwani AD. A stuck hemodialysis central venous catheter. J Vasc Access. 2008; 9(4): 301-3.

12. Ndzengue A, Kessaris N, Dosani T, Mustafa N, Papalois V, Hakim NS. Mechanical complications of long-term Tesio catheters. J Vasc Access. 2009; 10(1): 50-4. 